\title{
Kepemimpinan Tranformasional: Faktor Determinan Kinerja Karyawan Restoran Pada Hotel Marcure Nexa Pettarani Kota Makassar
}

\author{
${ }^{1}$ Abdi, ${ }^{2}$ Irva Yulia Rohmah \\ ${ }^{12}$ Politeknik Pariwisata Makassar \\ Makassar, Indonesia, 90224 \\ E-mail: didi@poltekpar-makassar.ac.id ; kireiva_jp07@yahoo.co.id
}

Received: 25 Februari 2020; Revised: 16 Maret 2020; Accepted: 20 April 2020

\begin{abstract}
Employee performance is an appearance of employee work both in quantity and high quality employee performance will support organizational productivity. This type of research used in this study is a quantitative approach. Quantitative research is used to examine a sample of the population with the analytical test method $n=$ Number of Samples $N=$ Number of population, and $E=$ Precision determined or the percentage of non-precision looseness. With the results employees have problems with the transformational leadership style that is applied by the restaurant employee supervisor at the Makassar Marcure Hotel Nexa Pettarani. The relationship between transformational leadership and employee performance is strengthened from the results of the regression analysis. The regression test results showed significant results on the transformational leadership variable on performance by 0.104 smaller than the error tolerance $\alpha=0.05$.
\end{abstract}

Keywords: Leadership; Transformational; Employee; Performance; Hotels

\begin{abstract}
Abstrak
Kinerja karyawan merupakan penampilan hasil kerja karyawan baik secara kuantitas maupun kualitas kinerja karyawan yang tinggi akan mendukung produktivitas organisasi. Jenis penelitian yang digunakan dalam penelitian ini adalah pendekatan kuantitatif. Penelitian kuantitatif digunakan untuk meneliti suatu sampel dari populasi dengan metode uji analisis $n=$ Jumlah Sampel $N=$ Jumlah populasi, dan $\mathrm{E}=$ Persisi yang di tetapkan atau presentase kelonggaran ketidak telitian. Dengan hasil karyawan memiliki permasalahan dengan gaya kepemimpinan transformasional yang diterapkan oleh atasan karyawan Restoran Pada Hotel Marcure Makassar Nexa Pettarani. Keterkaitan antara kepemimpinan transformasional dengan kinerja karyawan diperkuat dari hasil analisis regresi. Hasil uji regresi secara menunjukkan hasil yang signifikan pada variabel kepemimpinan transformasional terhadap kinerja sebesar 0,104 lebih kecil dari toleransi kesalahan $\alpha=0,05$.
\end{abstract}

Kata Kunci: Kepemimpinan; Transformasional; Kinerja; Karyawan; Hotel

Link DOI : http://dx.doi.org/10.31314/pjia.9.1.34-45.2020 


\section{PENDAHULUAN}

Masalah sumber daya manusia masih menjadi sorotan dan tumpuhan bagi organisasi untuk tetap dapat bertahan di era globalisasi. Hasbi \& Badollahi (2019) mennyatakan sumber daya manusia mempunyai peran utama dalam setiap kegiatan organisasi. Walaupun didukung dengan sarana dan prasarana serta sumber dana yang berlebihan, tetapi tanpa dukungan sumber daya manusia yang andal kegiatan organisasi tidak akan terselesaikan dengan baik. Dalam suatu perusahaan yang mana karyawan merupakan salah satu aset perusahaan yang penting dalam kepemimpinan merupakan dimana orang memberi pengaruh besar untuk menggerakkan setiap lingkuangannya (organisasi) untuk mencapai tujuan. Organisasi dan karyawan merupakan dua elemen yang saling membutuhkan dan tidak dapat dipisahkan satu dengan yang lainnya.

Karyawan pada umumnya memiliki potensi yang dapat memberikan kontribusi yang baik bagi organisasi, oleh karena itu sumber daya manusia (SDM) menjadi salah satu faktor produksi yang penting dalam upaya organisasi dalam mencapai tujuannya. Kelangsungan suatu organisasi sangat ditentukan oleh kinerja karyawan yang baik, sehingga diperlukan penilaian kinerja karyawan agar organisasi mengetahui sejauh mana karyawan berkontribusi terhadap pertumbuhan perusahaan(Rijal et al., 2019).

Pratama \& Setiawati menjelaskan bahwa "pemimpin transformasional menciptakan perubahan signifikan baik terhadap pengikutnya maupun terhadap organisasi. Pemimpin transformasional merupakan seorang agen perubahan yang berusaha keras melakukan perubahan-perubahan pada organisasi sehingga organisasi bisa mencapai kinerja yang lebih maksimal dimasa depan". Copyright (c) 2020, Publik (Jurnal Ilmu Administrasi), ISSN: 2301-573X (Print), ISSN: 2581-2084 (Online)
Kepemimpinan transformasional pada prinsipnya memotivasi karyawan untuk berbuat lebih baik dari apa yang biasa dilakukan, dengan kata lain dapat meningkatkan kepercayaan atau keyakinan diri bawahan yang akan berpengaruh terhadap peningkatan kerja. Walaupun didukung dengan sarana dan prasarana serta sumber dana yang berlebihan, tetapi tanpa dukungan sumber daya manusia yang andal kegiatan organisasi tidak akan terselesaikan dengan baik. Hal ini menunjukkan bahwa Kompetensi merupakan kunci pokok yang harus diperhatikan dengan segala kebutuhannya. sebagai kunci pokok, sumber daya manusia akan menentukan keberhasilan pelaksanaan kegiatan organisasi. Tuntutan organisasi untuk memperoleh, mengembangkan dan mempertahankan sumber daya manusia yang berkualitas semakin mendesak sesuai dengan dinamika lingkungan yang selalu berubah.

Menghadapi era persaingan usaha saat ini yang semakin ketat, kinerja yang dimiliki karyawan dituntut untuk terus meningkat, agar badan usaha tetap eksis maka harus berani menghadapinya yaitu menghadapi perubahan dan memenangkan persaingan (Hameed \& Waheed, 2011).

Mengingat kinerja menjadi hal yang sangat penting bagi manajemen untuk melakukan evaluasi terhadap kinerja dalam pencapaian tujuan perusahaan dan perencanaan di masa mendatang. Human Resource menjadi penggerak dan penentu jalannya organisasi, maka perhatian dari pimpinan sangat diperlukan dalam menentukan kinerja karyawan (Clinebell, et al., 2013).

Kinerja (job performance) berarti hasil kerja yang dapat dicapai oleh seseorang atau sekelompok orang dalam organisasi, sesuai dengan wewenang dan tanggung jawab masing-masing dalam rangka upaya mencapai tujuan organisasi 
bersangkutan secara legal, tidak melanggar hukum dan sesuai dengan moral etika (Arnando, 2015). Kinerja seorang karyawan berperan penting bagi suatu organisasi, karena kinerja setiap karyawan merupakan sumbangan bagi tercapainya kinerja setiap fungsi organisasi dan pada gilirannya kinerja fungsi-fungsi organisasi memberi sumbangan terhadap pencapaian kinerja organisasi (Falah \& Prasetya, 2017). Rendahnya kinerja karyawan dalam suatu organisasi dapat menyebabkan terhambatnya suatu organisasi dalam mencapai tujuannya. Kinerja dalam menjalankan fungsinya tidak berdiri sendiri, tetapi berhubungan dengan kepuasan kerja dan tingkat imbalan, dipengaruhi oleh keterampilan, kemampuan dan sifat-sifat individu (Putra \& Mujiati, 2016).

Kinerja karyawan merupakan penampilan hasil kerja karyawan baik secara kuantitas maupun kualitas dan merupakan suatu takaran atau ukuran apakah seorang karyawan telah melaksanakan tugas dan tanggung jawab yang telah diberikan perusahaan dengan sebaik-baiknya, kinerja karyawan yang tinggi akan mendukung produktivitas organisasi. Kinerja dapat berupa penampilan kerja perorangan maupun kelompok. Kinerja tinggi yaitu karyawan melaksanakan pekerjaan dengan penuh antusias dan bersemangat sehingga mampu mencapai target yang telah ditetapkan sebelumnya. Menurut pandangan (Gaffar, 2005) kinerja (performance) di pengaruhi oleh tiga faktor:Faktor individual yang terdiri dari kemampuan dan keahlian, latar belakang, demografi. Faktor psikologis, terdiri dari persepsi attitude (sikap), personality, pembelajaran, motivasi.

Faktor organisasi, terdiri dari sumber daya, kepemimpinan, penghargaan. Faktorfaktor ini tidak dapat berdiri sendiri namun merupakan suatu kesatuan yang saling terkait satu dengan yang lain, sehingga dapat dikatakan bahwa kinerja karyawan tidak hanya dipengaruhi oleh satu faktor saja. Bisa saja seseorang memiliki motivasi yang kuat atas pekerjaannya namun bila tidak memiliki hubungan yang harmonis sesama teman sekantor atau dengan pimpinan akan mengakibatkan terbentuknya suasana kerja yang tidak menyenangkan bagi dirinya yang dapat mengakibatkan rendahnya kinerja karyawan tersebut.

Kepemimpinan transformasional itu merupakan proses di mana orang terlibat dengan orang lain, dan menciptakan hubungan yang meningkatkan motivasi dan moralitas dalam diri pemimpin dan pengikut. Jenis pemimpin ini memiliki perhatian pada kebutuhan dan motif pengikut, serta mencoba membantu pengikut mencapai potensi terbaik mereka. Kepemimpinan transformasional yang murni, adalah kepemimpinan yang bersifat sosial dan peduli dengan kebaikan bersama. Pemimpin transformasional yang bersifat sosial ini mengalahkan kepentingan mereka sendiri demi kebaikan orang lain. Modiani (2012) kepemimpinan transformasional merupakan kemampuan untuk memberikan inspirasi dan memotivasi para pengikutnya untuk mencapai hasil-hasil yang lebih besar daripada yang direncanakan secara orisinil dan untuk imbalan internal. Dari defenisi di atas dapat disimpulkan bahwa gaya kepemipinan transformasional adalah cara yang digunakan seorang pemimpin untuk mempengaruhi bawahannya untuk meningkatkan kinerja karyawan dalam rangka mencapai tujuan organisasi secara efektif dan efesien. Dalam penelitian terdahulu yang ditulis oleh Barlian (2017), yang menunjukkan bahwa faktor Determinan Kepemimpinan dan Kepuasan 
Kerja Karyawan memiliki pengaruh dan penelitian

Rachman \& Marsuq menemukan faktor kepemimpinan memberikan kesempatan pada karyawan untuk berkembang. Selanjutnya penelitian ini memiliki urgensi untuk melihat bagaimana kepemimpinan dari aspek yang berbeda yaitu pada kepemimpinan tranformasional dari faktor determinan kinerja karyawan.

\section{METODE PENELITIAN}

Pendekatan penelitian yang digunakan dalam penelitian ini adalah pendekatan kuantitatif dengan tujuan memverifikasi ada tidaknya faktor determinan kinerja karyawan restoran pada hotel marcure makassar nexa pettarani kota makassar. Data kuantitatif, yaitu data yang di nyatakan dalam bentuk angka-angka yang dapat dihitung. Dalam penelitian ini yang di maksud data kuantitatif adalah jumlah pegawai, hasil Analisa data penelitian data kualitatif, yaitu data yangtidak dapat di nyatakasn dalam bentuk angka-angka. Dalam penelitian ini yang termaksud data kualitatif gambaran umum lokasi penelitian.

Penelitian ini secara khusus, dilaksanakan pada Marcure Makassar Nexa Pettarani. Adapun waktu penelitian yang digunakan kurang lebih 2 (dua) bulan yang berlangsung sejak bulan Desember sampai dengan January 2019. Sedangkan jangka waktu penelitian untuk menyelesaikan penulisan serta pengolahan datanya diperkirakan kurang lebih 1 (satu) bulan. Populasi dalam penelitian ini adalah pegawai/karyawan Marcure Makassar Nexa Pettarani beralamat di Jalan A.P Pettarani No 4 Gunung Sari Rappocini 90222 Kota Makassar, Provinsi Sulawesi Selatan. Mempekerjakan 112 orang pegawai. Jumlah populasi dalam penelitian ini adalah sebanyak 100 orang, Persisi pengambilan sampel adalah $100 \%$ untuk menjaga representative dari sampel sampel penelitian.

\section{HASIL DAN PEMBAHASAN}

Restoran sebagai sebuah industri yang bergerak di bidang pelayanan jasa tentunya selalu berusaha memberikan pelayanan terbaik bagi para tamu atau konsumennya. Sebagai industri pelayanan jasa khususnya restoran, kepuasan tamu merupakan tujuan utama yang harus tercapai juga sebagai kunci kesuksesan industri itu sendiri. Saat ini restoran merupakan salah satu jenis industri yang berkembang dengan sangat pesat. Hal ini dapat dilihat dengan banyak berdirinya hotel-hotel baru di bebagai daerah, Perkembangan industri perhotelan ini tidak lepas dari dampak pertumbuhan ekonomi dan kemajuan teknologi, dimana pada masa sekarang ini hotel menjadi salah satu akomodasi utama yang dibutuhkan seseorang ketika bepergian, baik untuk kepentingan pribadi maupun kepentingan bisnis atau perusahaan. Dengan perkembangan dan perubahan yang terjadi menyebabkan perubahan pola pikir dari sisi tamu atau konsumen yang ingin menggunakan fasilitas hotel. Tamu atau konsumen pada saat ini menjadi lebih kritis dalam menentukan pilihan hotel yang akan digunakannya. Sehingga faktor yang dapat mendatangkan kepuasan bagi tamu atau konsumen menjadi lebih kompleks sesuai dengan yang diinginkan. Hal ini tentu saja menjadi "PR" tersendiri bagi sebuah industri hotel untuk dapat meningkatkan produk dan layanannya sebagai usaha untuk memberikan kepuasan terhadap tamu atau konsumennya. Namun, sebagai sebuah industri, kepuasan tamu atau konsumen bukanlah satu-satunya tujuan yang harus dicapai. Tujuan lain selain kepuasan tamu atau konsumen adalah pemasukan atau keuntungan yang harus Copyright (c) 2020, Publik (Jurnal Ilmu Administrasi), ISSN: 2301-573X (Print), ISSN: 2581-2084 (Online) 
dicapai demi keberlangsungan industri hotel itu sendiri.

Perkembangan yang pesat di dalam industri perhotelan membawa dampak tersendiri, salah satunya adalah timbulnya persaingan antar hotel. Fakta di lapangan saat ini adalah tidak semua hotel mampu bersaing dan berkembang sesuai dengan tuntutan perkembangan yang terjadi. Hal ini dapat dilihat dari banyaknya hotel yang namanya meredup terlupakan oleh calon tamu atau konsumen sehingga pada akhirnya gulung tikar. Hotel yang tidak mampu bersaing dan berkembang tentu saja akan dinilai tidak dapat memberikan kepuasan terhadap tamu atau konsumennya, baik dari segi produk maupun layanannya sehingga calon tamu atau konsumen tidak akan menjadikan hotel tersebut sebagai pilihan destinasi hotel yang ingin digunakan. Hal seperti inilah yang sangat dihindari oleh manajemen Hotel dan restoran, sehingga Hotel dan restoran terus melakukan perubahan baik peningkatan maupun inovasi produk dan layanannya agar selalu sesuai dengan kebutuhan dan keinginan calon tamu atau konsumennya.

Model penggambaran mengenai informasi jawaban responden terhadap butir-butir pernyataan kuesioner pada variabel-variabel penelitian adalah dengan menggunakan presentase. Berikut ini adalah hasil pengolahan kuesioner atas tanggapan responden terhadap indikatorindikator yang menjadi item pertanyaan pada kuesioner dan juga perhitungan skor bagi variabel gaya kepemimpinan, komunikasi, kompetensi dan kinerja karyawan.

Distribusi Jawaban Responden Gaya Kepemimpinan (X1) Variabel Gaya Kepemimpinan (X1) pada penelitian ini diukur melalui 9 pernyataan yang mempresentasikan dimensi dan indikator dari variabel tersebut. Di dalam kuesioner, 9 pertanyaan pada variabel Gaya Kepemimpinan berdimensi gaya kepemimpinan autokratis, gaya kepemimpinan birokratik, gaya kepemimpinan diplomatis, gaya kepemimpinan partisipatif, dan gaya kepemimpinan free rein leade. Setiap dimensi mempunyai beberapa indikator yang direpresentasikan dalam pertanyaan.

Distribusi Jawaban Responden Variabel Gaya Kepemimpinan (X1) menunjukkan bahwa mayoritas responden menjawab Setuju (S) dengan persentase sebesar $54,4 \%$ dari $100 \%$, sisanya menjawab Sangat Setuju (SS) sebesar $40.4 \%$, Netral (N) sebesar 4.8\%, Tidak Setuju (TS) sebesar $0.2 \%$ dan Sangat Tidak Setuju (STS) sebesar 0\%. Distribusi Jawaban Responden Mengenai Kinerja Pegawai (Y) Variabel Kinerja (Y) pada penelitian ini diukur melalui 6 pernyataan yang mempresentasikan indikatorindikator dari variabel tersebut.

Distribusi Jawaban Responden Variabel Kinerja (Y), menunjukkan bahwa mayoritas responden menjawab Setuju (S) dengan persentase sebesar 35\% dari 100\%, sisanya menjawab Sangat Setuju (SS) sebesar $27.5 \%$, Netral (N) sebesar $18.8 \%$, Tidak Setuju (TS) sebesar 16\% dan Sangat Tidak Setuju (STS) sebesar 0\%.

\section{Hasil Uji Statistik}

Model penggambaran mengenai informasi jawaban responden terhadap butir-butir pernyataan kuesioner pada variabel-variabel penelitian adalah dengan menggunakan presentase. Berikut ini adalah hasil pengolahan kuesioner atas tanggapan responden terhadap indikatorindikator yang menjadi item pertanyaan pada kuesioner dan juga perhitungan skor bagi variabel gaya kepemimpinan, Komunikasi, kompetensi dan kinerja 
karyawan Restoran Pada Hotel Marcure Makassar.

Pengujian yang dilakukan dalam penelitian ini meliputi: statistik deskriptif, uji kualitas data (uji validitas dan uji reliabilitas), uji asumsi klasik (uji normalitas, uji heteroskedastisitas, dan uji linearitas), analisis regresi linear berganda, serta uji hipotesis (uji analisis pearson dan analisa koefisien determinasi).

Cara pengkategorian data tersebut adalah sebagai berikut:

Tinggi $=$ mean $+\mathrm{SD} \leq \mathrm{X}$

Sedang $=$ mean $-\mathrm{SD} \leq \mathrm{X}<$ mean $+\mathrm{SD}$

Rendah $=X<$ mean - SD

Variabel yang digunakan dalam penelitian ini meliputi gaya kepemimpinan, komunikasi, kompetensi dan kinerja karyawan dilihat dari statistik deskriptif adalah sebagai berikut:

Tabel 1. Hasil Analisis Deskriptif (Descriptive Statistics)

\begin{tabular}{lccccl}
\hline & N & Min & Max & Mean & $\begin{array}{l}\text { Std. } \\
\text { Deviation }\end{array}$ \\
\hline Kepemimpinan & 100 & 31 & 45 & 39.09 & $\mathbf{3 . 9 7 5}$ \\
Valid N (listwise) & $\mathbf{1 0 0}$ & & & & \\
\hline
\end{tabular}

Sumber : Hasil Olahan Data Primer

Tabel 1, menjelaskan bahwa variabel gaya kepemimpinan tranformasional, jawaban minimum responden sebesar 31 dan maksimum sebesar 45, dengan rata-rata total jawaban 39.09 dan standar deviasi 3.975. Hasil Uji Kualitas Data.

\section{Hasil Uji Validitas}

Uji validitas bertujuan untuk mengukur sah atau valid tidaknya suatu kuesioner. Suatu kuesioner dikatakan valid jika pertanyaan pada kuesioner mampu mengungkapkan sesuatu yang akan diukur oleh kuesioner tersebut. Hasil uji validitas dikatakan valid apabila nilai probabilitasnya lebih kecil dari 0,05 sedangkan nilai probabilitas lebih besar dari 0,05 menunjukkan bahwa item pernyataan tersebut tidak valid. Dasar pengambilan keputusannya adalah:

Jika $r_{\text {hitung }}>r_{\text {tabel }}=$ pernyataan di anggap valid

Jika $r_{\text {hitung }}<r_{\text {tabel }}=$ pernyataan di anggap tidak valid

Hasil pengujian diperoleh sebagai berikut: Tabel 2. Uji Validitas

\begin{tabular}{llll}
\hline Item & $\mathbf{r}$ & $\mathbf{r}$ & Keterangan \\
Pertanyaan & hitung & tabel & \\
\hline
\end{tabular}

\begin{tabular}{llll}
\hline \multicolumn{4}{c}{ Kepemimpinan tranformasional $\left(\mathbf{X}_{\mathbf{1}}\right)$} \\
Item 1 & 0,677 & 0,284 & Valid \\
Item 2 & 0,702 & 0,284 & Valid \\
Item 3 & 0,624 & 0,284 & Valid \\
Item 4 & 0,631 & 0,284 & Valid \\
Item 5 & 0,667 & 0,284 & Valid \\
Item 6 & 0,677 & 0,284 & Valid \\
Item 7 & 0,679 & 0,284 & Valid \\
Item 8 & 0,575 & 0,284 & Valid \\
Item 9 & $\mathbf{0 , 6 8 5}$ & $\mathbf{0 , 2 8 4}$ & Valid \\
\hline
\end{tabular}

Sumber: Hasil Olahan Data Primer

Pada uji validitas dengan membandingkan nilai $r_{\text {hitung }}$ dengan $r_{\text {tabel }}$ untuk degree of freedom $(\mathrm{df})=\mathrm{n}-2$ ( $\mathrm{n}$ adalah jumlah sampel pembentuk regresi). Kuesioner penelitian ini menggunakan 100 responden, penentuan $r_{\text {tabel }}$ adalah $(\mathrm{df})=100-2=98$. Dengan menggunakan tingkat signifikansi sebesar $5 \%$, maka nilai $r_{\text {tabel }}$ adalah 0,2516. Uji validitas dihitung dengan membandingkan nilai $r$ hitung (correlated item-total correlation) dengan nilai $r$ tabel, jika $r$ hitung $>\mathrm{r}$ table (pada taraf signifikansi 
5\%) maka pernyataan tersebut dinyatakan valid. Dari hasil tersebut, maka diperoleh data yang menyatakan bahwa dari 33 item pertanyaan yang diberikan kepada 100 responden ditemukan nilai Pearson Correlation lebih besar dari 0,284 (rtabel) yang berarti valid. Hal ini menunjukkan bahwa setiap pertanyaan yang diajukan kepada responden dari setiap pertanyaan tiap variabel pada penelitian ini mampu mengukur apa yang diinginkan oleh responden.

\section{Pengujian Asumsi Klasik}

Uji asumsi klasik yang digunakan dalam penelitian ini meliputi uji normalitas uji liniearitas dan uji heteroskedastisitas. Berikut ini dipaparkan masing-masing uji asumsi klasik pada masing-masing variabel penelitian. Uji normalitas dilakukan untuk melihat apakah nilai residual terdistribusi normal atau tidak. Uji normalitas bertujuan untuk menguji salah satu asumsi dasar analisis regresi berganda, yaitu variabel-variabel independen dan dependen harus berdistribusi normal atau mendekati normal (Ghozali, 2016). Uji statistik sederhana yang digunakan untuk menguji asumsi normalitas adalah dengan menggunakan uji normalitas dari Kolmogorov Smirnov. Metode pengujian normal tidaknya distribusi data dilakukan dengan melihat nilai signifikansi variabel, jika signifikan lebih besar dari 0,05 pada taraf signifikansi alpha 5\%, maka menunjukkan distribusi data normal. Hasil pengujian diperoleh hasil sebagai berikut:

Tabel 3. Uji Normalitas

\begin{tabular}{lcc}
\hline Variabel & Sig. & Kesimpulan \\
\hline $\begin{array}{l}\text { Kepemimpinan } \\
\text { Transformasional } \\
\text { (X1) }\end{array}$ & $\mathbf{0 . 2 8 5}$ & Normal \\
\hline
\end{tabular}

Sumber : Hasil Olahan Data Primer
Disimpulkan bahwa semua variabel adalah normal. Hal ini dapat dilihat dari tingkat signifikansi) semua diatas 0,285. disimpulkan bahwa variabel kepemimpinan transformasional, tersebut berdistribusi normal, sehingga dapat dianalisa lebih lanjut.

Nilai Tolerance semua variabel independen $>0,10$ dan nilai VIF semua variabel independen $<10,00$, yang ditunjukkan dengan nilai Tolerance untuk gaya kepemimpinan sebesar 0,429. Dengan demikian dapat disimpulkan bahwa model persamaan regresi tidak terdapat problem multiko atau dapat dikatakan bebas dari problem multikolinearitas dan dapat digunakan dalam penelitian ini.

\section{Uji Heteroskedastisitas}

Uji Heteroskedastisitas bertujuan menguji apakah dalam model regresi terjadi ketidaksamaan variance dari residual satu pengamatan ke pengamatan yang lain. Jika variance dari residual satu pengamatan ke pengamatan lain tetap, maka disebut homokesdastisitas dan jika berbeda disebut heteroskedastisitas. Model regresi yang baik adalah yang tidak terjadi heteroskesdatisitas (Ghozali, 2016). Uji untuk mendeteksi adanya gejala heteroskedastisitas dilakukan dengan uji.

Tabel 4. Hasil Uji Heteroskedastisitas

\begin{tabular}{ccl}
\hline Variabel & Sig. & Kesimpulan \\
\hline $\mathrm{X}_{1} \mathrm{Y}$ & $\mathbf{0 , 6 6}$ & $\begin{array}{l}\text { Bebas } \\
\text { heteroskedastisitas }\end{array}$ \\
\hline
\end{tabular}

Sumber : Hasil Olahan Data Primer

Dari hasil uji heteroskedastisitas yang menggunakan statistik uji glejser diperoleh nilai signifikansi untuk semua variabel independen (kepemimpinan transformasional,) terhadap dependen (kinerja) lebih besar dari taraf kesalahan $5 \%(0,05)$ sehingga dapat disimpulkan 
variabel penelitian bebas dari heteroskedastisitas.

\section{Uji Reabilitas}

Realibilitas adalah alat untuk mengukur suatu kuisioner yang merupakan indikator dari variabel atau konstruk. Suatu kuisioner dikatakan reliabel atau handal jika jawaban seseorang terhadap pernyataan adalah konsisten atau stabil dari waktu ke waktu. Kriteria pengujian dilakukan dengan menggunakan pengujian Cronbach Alpha $(\alpha)$. Suatu variabel dikatakan reliable jika memberikan nilai Cronbach Alpha > 0,60 (Nunnaly, 1994 dalam Ghozali, 2016).

Tabel 5. Uji Reabilitas

\section{Reliability Statistics}

\begin{tabular}{ll}
\hline Cronbach's Alpha & N of Items \\
.960 & 33
\end{tabular}

\section{Sumber : Hasil Olahan Data Primer}

Variabel yang berkaitan dengan variabel independen (kepemimpinan,) dalam kuisoner dikatakan reliabel. Hal ini dapat dilihat dari nilai Cronbach's Alpha yang positif, berturut-turut 0.959, 0.959, 0,960 dan 0.963 lebih besar dari 0.60. dengan demikian dapat dikatakan bahwa seluruh pernyataan pada penelitian ini memiliki tingkat kehandalan yang baik dan dapat digunakan dalam analisis dalam penelitian ini.

\section{Uji Liniearitas}

Uji liniearitas bertujuan untuk mengetahui apakah dua variabel mempunyai hubungan yang linear atau tidak secara signifikan. Uji ini digunakan untuk melihat apakah spesifikasi model yang digunakan sudah benar atau belum (Ghozali, 2011:166). Uji ini biasanya digunakan sebagai prasyarat dalam analisis Copyright (c) 2020, Publik (Jurnal Ilmu Administrasi), ISSN: 2301-573X (Print), ISSN: 2581-2084 (Online) regresi linier. Dua variabel dikatakan mempunyai hubungan yang linier bila signifikasi lebih besar dari 0,05. Data hasil uji linieritas dapat dilihat pada tabel 6. Dari tabel 6 tersebut dapat disimpulkan bahwa semua variabel independen linear terhadap variabel dependen. Hal ini dapat dilihat dari tingkat signifikansi semua diatas 0,05 .

\section{Analisis Linear Berganda}

Hipotesis dalam penelitian ini diuji dengan menggunakan model regresi linear berganda. Ghozali (2016) mengatakan regresi linear berganda digunakan untuk menguji pengaruh satu variabel terikat (dependen) dan dua atau lebih variabel bebas (independen). Tujuan penerapan metode ini adalah untuk meramalkan atau memprediksi besaran nilai variabel terikat (dependen) yang dipengaruhi oleh variabel bebas (independen). hasil uji regresi linear berganda dapat dilihat pada Tabel 7 .

Berdasarkan tabel 7, maka nilai konstanta dan koefisien regresi dapat dibentuk menjadi :

$$
Y=1.233+0,104 X_{1}+0,035 X_{2}+0,459 \times 3
$$

Dari persamaan diatas dapat dijelaskan sebagai berikut:

1. Nilai konstanta (a) adalah menunjukan besarnya nilai kinerja karyawan (Y). Variabel gaya kepemimpinan dan kompetensi dinyatakan konstan dengan nilai kinerja pegawai sebesar 1.233.

2. Koefisien regresi variabel gaya kepemimpinan $\left(\mathrm{X}_{1}\right)$ sebesar 0,104 maka menyatakan bahwa adanya pengaruh antara gaya kepemimpinan dengan kinerja karyawan, jika semakin baik gaya kepemimpinan maka kinerja karyawan akan meningkat positif. Dimana semakin baik gaya kepemimpinan maka semakin meningkatkan kinerja karyawan. 


\section{Tabel 6 Uji Linearitas} ANOVA Table

\begin{tabular}{|c|c|c|c|c|c|c|c|}
\hline & & & $\begin{array}{l}\text { Sum of } \\
\text { Squares }\end{array}$ & Df & $\begin{array}{l}\text { Mean } \\
\text { Square }\end{array}$ & $\mathrm{F}$ & Sig. \\
\hline \multirow{5}{*}{$\begin{array}{l}\text { kinerja * } \\
\text { kepemimpinan }\end{array}$} & \multirow{3}{*}{$\begin{array}{l}\text { Between } \\
\text { Groups }\end{array}$} & (Combined) & 453.080 & 13 & 34.852 & 4.383 & .000 \\
\hline & & Linearity & 353.867 & 1 & 353.867 & 44.498 & .000 \\
\hline & & $\begin{array}{l}\text { Deviation } \\
\text { from } \\
\text { Linearity }\end{array}$ & 99.214 & 12 & 8.268 & 1.040 & .421 \\
\hline & Within Groups & & 683.910 & 86 & 7.952 & & \\
\hline & Total & & 1136.990 & 99 & & & \\
\hline
\end{tabular}

Sumber : Hasil Olahan Data Primer

Tabel 7 Analisis Linear Berganda

\begin{tabular}{|c|c|c|c|c|c|c|}
\hline \multicolumn{7}{|c|}{ Coefficients $^{\mathrm{a}}$} \\
\hline \multirow{2}{*}{\multicolumn{2}{|c|}{ Model }} & \multicolumn{2}{|c|}{$\begin{array}{l}\text { Unstandardized } \\
\text { Coefficients }\end{array}$} & $\begin{array}{l}\text { Standardiz } \\
\text { ed }\end{array}$ & $\mathrm{t}$ & Sig. \\
\hline & & B & Std. Error & Beta & & \\
\hline \multirow[t]{4}{*}{1} & (Constant) & 1.233 & 2.797 & & .441 & .660 \\
\hline & Kepemimpinan & .104 & .097 & .122 & 1.075 & .285 \\
\hline & & .035 & .082 & .042 & .432 & .667 \\
\hline & & .459 & .095 & .560 & 4.837 & .000 \\
\hline a. & Dependent Var & inerja & & & & \\
\hline
\end{tabular}

Tabel 8 Hasil Uji Koefisien Determinasi

\begin{tabular}{lcccc}
\hline \multicolumn{1}{c}{ Variabel } & $\mathrm{R}$ & $\mathrm{R}^{2}$ & Adjusted $\mathrm{R}^{2}$ & Standar \\
\hline Kinerja & 0,682 & 0,465 & 0,449 & 0,25166 \\
\hline
\end{tabular}

Sumber : Hasil Olahan Data Primer

3. Koefisien regresi variabel komunikasi $\left(\mathrm{X}_{2}\right)$ sebesar 0,035 maka menyatakan bahwa adanya pengaruh antara lomunikasi dengan kinerja karyawan jika semakin baik komunikasi yang dimiliki karyawan maka kinerja karyawan akan meningkat positif. Semakin baik dan tinggi komunikasi maka semakin meningkatkan kinerja pegawai.

4. Koefisien regresi variabel kompetensi $\left(\mathrm{X}_{3}\right)$ sebesar 0,459 maka menyatakan bahwa adanya pengaruh antara kompetensi dengan kinerja karyawan, jika semakin baik kompetensi yang dimiliki pegawai maka kinerja karyawan akan meningkat positif. 
Publik (Jurnal Ilmu Administrasi) Vol 9 (1), Juni 2020

\section{Analisa Koefesien Determinasi}

Koefisien Determinasi $\left(\mathrm{R}^{2}\right)$ digunakan untuk mengetahui seberapa jauh kemampuan model dalam menerangkan variasi variabel dependen. dan satu. Nilai yang mendekati satu berarti variabel-variabel independen memberikan hampir semua informasi yang dibutuhkan untuk memprediksi variasi variabel dependen (Ghozali, 2011). Hasil uji koefisien determinasi dapat dilihat di Tabel 8.

Berdasarkan Tabel 8 dapat terlihat bahwa Adjusted $\mathrm{R}^{2}$ sebesar 0,465, maka dapat disimpulkan bahwa kepemimpinan transformasional, komunikasi dan kompetensi secara simultan mempengaruhi kinerja karyawan sebesar 44,9\%, dan sisanya sebesar $55,1 \%$ dipengaruhi oleh faktor lain diluar variabel penelitian yang digunakan.

\section{Kepemimpinan Transformasional terhadap Kinerja Karyawan Restoran Pada Hotel Marcure Makassar}

Hasil penelitian ini menunjukkan bahwa gaya kepemimpinan transformasional berpengaruh positif dan signifikan terhadap kinerja. Pengaruh gaya kepemimpinan transformasional terhadap kinerja, dikemukaan dalam penelitian Tucunan, dkk (2014) yang mengatakan bahwa kepemimpinan transformasional memiliki pengaruh terhadap kinerja karyawan. Tucunan, dkk menyatakan bahwa gaya kepemimpinan transformasional berpengaruh positif terhadap kinerja karyawan Pada PT Pandawa dengan cara melakukan pendekatan yang baik dan ramah kepada bawahan, sehingga bawahan merasa senang dengan cara pemimpin memberikan arahan dan masukan untuk mencapai kinerja yang lebih baik. Alasan ini diperkuat oleh teori oleh Robbins \& Nilai koefisien determinasi $\left(\mathrm{R}^{2}\right)$ antara nol

Judge (2003) yang dalam penjelasannya disebutkan bahwa pemimpin mampu merangsang agar bawahan dapat berfikir secara kreatif dan inovatif.

Gaya

kepemimpinan transformasional berpengaruh positif dan signifikan terhadap kinerja hal ini sejalan dengan penelitian Tucunan (2014). Dan juga dalam variabel yang lebih kompleks pada penelitian Supriyanto \& Troena (2012). Menunjukkan pengaruh Kecerdasan Emosional dan kecerdasan spiritual terhadap kepemimpinan Transformasional.

Dari hasil penelitian yang dilakukan oleh peneliti dapat diketahui bahwa karyawan memiliki permasalahan dengan gaya kepemimpinan transformasional yang diterapkan oleh atasan karyawan Restoran Pada Hotel Marcure. Keterkaitan antara kepemimpinan transformasional dengan kinerja karyawan diperkuat dari hasil analisis regresi. Hasil uji regresi secara menunjukkan hasil yang signifikan pada variabel kepemimpinan transformasional terhadap kinerja sebesar 0,104 lebih kecil dari toleransi kesalahan $\boldsymbol{\alpha}=\boldsymbol{0 , 0 5}$. Pengaruh yang ditimbulkan bersifat negatif dan signifikan, artinya gaya kepemimpinan transformasional yang diterapkan oleh atasan karyawan menimbulkan hasil kerja yang menurun. Hasil uji t diketahui bahwa nilai t hitung bernilai 1.233. Hasil penelitian ini menunjukkan bahwa kepemimpinan transformasional berpengaruh positif dan signifikan terhadap kinerja karyawan.

\section{PENUTUP}

\section{Kesimpulan}

Hasil penelitian menunjukan besarnya nilai kinerja karyawan (Y). Variabel gaya kepemimpinan dan kompetensi dinyatakan konstan dengan nilai kinerja pegawai sebesar 1.233 dan Copyright (c) 2020, Publik (Jurnal Ilmu Administrasi), ISSN: 2301-573X (Print), ISSN: 2581-2084 (Online) 
koefisien regresi variabel gaya kepemimpinan $\left(\mathrm{X}_{1}\right)$ sebesar 0,104 maka menyatakan bahwa adanya pengaruh antara gaya kepemimpinan dengan kinerja karyawan, jika semakin baik gaya kepemimpinan maka kinerja karyawan akan meningkat positif. Dimana semakin baik gaya kepemimpinan maka semakin meningkatkan kinerja karyawan.

\section{Saran}

Diharapkan gaya kepemimpinan transformasional dapat selalu diterapkan di organisasi yang menginginkan peningkatan kinerja positif dari para karyawan/pegawai, baik itu di organisasi privat maupun organisasi pemerintahan, dengan begitu gaya kepemimpinantransformasional dapat menjadi rekomendasi bagi para pimpinan yang menjadi leader di unit kerjanya.

\section{DAFTAR PUSTAKA}

Arnando, S. O. (2015). Pengaruh gaya kepemimpinan perempuan terhadap kinerja karyawan (survei terhadap karyawan divisi corporate communication pada pt. freeport indonesia). Doctoral dissertation, Universitas Multimedia Nusantara.

Barlian, N. A. (2017). Faktor Determinan Kepemimpinan dan Kepuasan Kerja Karyawan di Klinik Husada Mulia Kabupaten Lumajang. ASSETSJurnal Ilmiah Ilmu Akuntansi, Keuangan dan Pajak, 1(2), 115-123.

Clinebell, S., Skudiene, V., Trijonyte, R., \& Reardon, J. (2013). Impact of leadership styles on employee organizational commitment. Journal of Service Science (JSS), 6(1), 139152.

Falah, N. A. S., \& Prasetya, A. (2017). Pengaruh Knowledge Management Terhadap Kinerja Karyawan Dan
Kinerja Perusahaan (Studi pada Karyawan PT Semen Indonesia Persero Tbk). Jurnal Administrasi Bisnis, 50(4), 192-198.

Gaffar, M. R. (2005). Pengaruh Knowledge Management Pada Performansi Kerja Sumber Daya Manusia di Perusahaan ICT Indonesia. Telkom University.

Ghozali, I. (2016). Desain penelitian kuantitatif dan kualitatif untuk akuntansi, bisnis, dan ilmu sosial lainnya. Semarang: Yoga Pratama.

Hameed, A., \& Waheed, A. (2011). Employee development and its affect on employee performance a conceptual framework. International journal of business and social science, 2(13).

Hasbi, A., \& Badollahi, M. Z. (2019). Analisis Partisipasi Masyarakat dan Pemerintah dalam Pengembangan Sektor Pariwisata Kabupaten Bone, Sulawesi Selatan. Pusaka: Journal of Tourism, Hospitality, Travel and Business Event, 1(2), 15-27.

Modiani (2012). Pengaruh Kepemimpinan Transformasional Terhadap Kinerja Karyawan PT PLN (Persero) UPJ Semarang. Thesis, Universitas Semarang.

Pratama, D. W., \& Setiawati, T. (2015). Hubungan antara gaya kepemimpinan transformasional dan komitmen karyawan di pamella swalayan enam yogyakarta. Manajemen SDM, 1-22.

Putra, I. P. P., \& Mujiati, N. W. (2016). Pengaruh Kompetensi, Kompensasi Finansial Dan Motivasi Kerja Pada Kepuasan Kerja Karyawan Take

44 Copyright $@$ C 2020, Publik (Jurnal Ilmu Administrasi), ISSN: 2301-573X (Print), ISSN: 25812084 (Online) 
Japanese Restaurant Legian Kuta

Badung Bali. E-Jurnal Manajemen

Unud, 5(1), 260-292.

Rachman, M., \& Marsuq, M. (2020). Capability of Dynamic Governance Aspects of Thinking Across: Case Studies in Building and Environmental Planning in Strategic Areas. Journal La Bisecoman, 1(2), 20-24.

Rijal, S., Sukarana, M., \& Zainuddin, M. (2019). The Role of Income Audit against the Internal Control at Hotel Gammara Makassar. 9(6), 116-125.

Robbins, S. P., \& Judge, T. (2003). Essentials of organizational behavior (Vol. 7). Upper Saddle River, NJ: Prentice Hall.

Tucunan, R. J. A., Supartha, W. G., \& Riana, I. G. (2014). Pengaruh Kepemimpinan Transformasional terhadap Motivasi dan kinerja Karyawan. E-jurnal ekonomi dan Bisnis Universitas Udayana, 3(09), 533-550. 